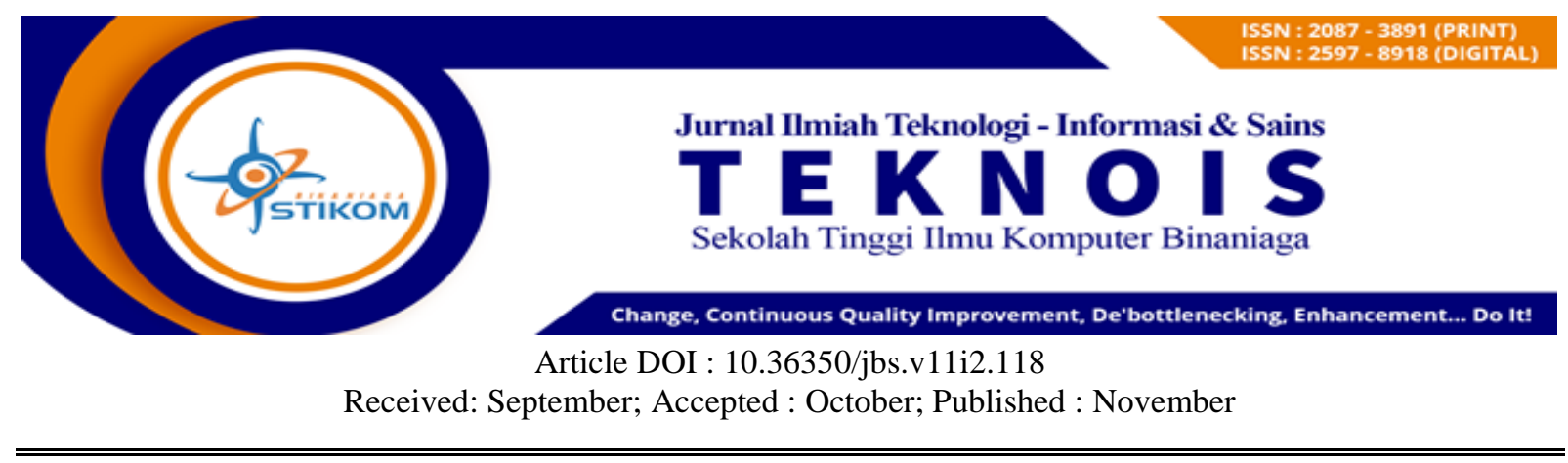

\title{
Perancangan Penerapan Quick Response (QR) Kode Dalam Sistem Pendaftaran
}

\author{
Mochamad Sanwasih ${ }^{1 *}$, Rachmat Setiabudi ${ }^{2}$ \\ ${ }^{1}$ Sistem Informasi/Universitas Binaniga Indonesia \\ Email: mochamadsanwasih11@gmail.com \\ ${ }^{2}$ Sistem Informasi/ Universitas Binaniga Indonesia \\ Email: raffisetiabudi@gmail.com
}

\begin{abstract}
The rapid development of technology and information systems has now been able to attract the attention of many organizations to support their activities, one of which is the development of an online registration system. There are problems that occur due to the unavailability or lack of use of the technology. Systems that are still manual processing can cause problems in the future. One of them is from problems that occur in poor data management, ambiguous participant data, the use of time used to be wasted and other obstacles. The application of the Quick Response $(Q R)$ code in the registration system is expected to help problems that occur so that data management becomes better and creates a more efficient and structured use of time. The system development of this registration system design uses the SDLC method and the model used is the waterfall model, which provides an overview from the analysis to the maintenance of the information system of the designed application. The system design to facilitate research analysis of the system to be used, uses the Unified Modeling Language (UML) with the modeling used is the Waterfall model, which describes the flow of the existing system that will be developed
\end{abstract}

Keywords: Quick Response (QR), Unified Modeling Language (UML), SDLC; Waterfall Model; Application.

\section{ABSTRAK}

Perkembangan teknologi dan sistem informasi yang begitu pesat sekarang ini telah mampu menarik perhatian banyak organisasi untuk mendukung dalam kegiatannya salah satunya dalam pengembangan sistem pendaftaran secara online. Adanya permasalahan yang terjadi disebabkan belum tersedianya atau belum adanya pemakaian teknologi tersebut. Sistem yang masih manual pengerjaannya bisa menimbulkan kendala kedepannya. Salah satunya dari permasalahan yang terjadi pengelolaan data yang kurang baik, data peserta yang rancu, pemanfaatan waktu yang digunakan menjadi banyak terbuang dan kendala yang lainnya. Penerapan kode Quick Response (QR) dalam sistem pendaftaran diharapkan dapat membantu permasalahan yang terjadi sehingga pengelolaan data menjadi lebih baik dan terciptanya penggunaan waktu yang lebih efisien dan lebih terstruktur. Pengembangan sistem dari perancangan sistem pendaftaran ini menggunakan metode SDLC dan model yang digunakan adalah model waterfall, yang memberikan gambaran dari mulai analisa sampai dengan pemeliharaan sistem informasi dari aplikasi yang dirancang. Perancangan sistem untuk memudahkan penganalisaan penelitian dari sistem yang akan digunakan, menggunakan Unified Modeling Language (UML) dengan pemodelan yang 
Volume 11 Number 2 November 2021 Page. 85-94

Journal Homepage : http://teknois.stikombinaniaga.ac.id/index.php/JBS

DOI Link : http://doi.org/10.36350/jbs.v11i2

digunakan adalah model Air Terjun (waterfall), yang menggambarkan alur dari sistem yang ada yang yang akan dikembangkan.

Keywords: Quick Response (QR), Unified Modeling Language (UML), SDLC; Waterfall Model; Aplikasi..

\section{A. PENDAHULUAN}

\section{Latar Belakang}

Keamanan suatu sistem sangat diperlukan untuk menjaga agar data tidak mudah untuk dirubah atau terjadinya manipulasi data yang bisa saja terjadi. Perkembangan teknologi turut berjasa untuk pengembangan keamanan. Contoh dalam pengembangan sistem dalam pendaftaran suatu acara yang tengah terjadi. Penerapan sistem yang masih bersifat manual bisa menjadi kendala dalam pengelolaan data yang baik.

Sistem yang masih bersifat manual bisa menghambat percepatan informasi yang dibutuhkan, disamping pengelolaan data yang bisa membuat lambatnya proses yang terjadi. Seperti contoh sistem pendaftaran yang masih dijalankan dengan sistem pendaftaran langsung datang ke lokasi pendaftaran. Dapat dilihat dari sisi waktu yang terjadi, apabila tempat pendaftaran tersebut lokasi berada dilokasi yang jauh atau susah untuk didatangi dan membutuhkan waktu yang lama, hal terebut akan menjadi kendala.

Dalam sistem pendaftaran terdapat beberapa langkah atau tahapan, yang pertama pengguna atau pendaftar harus datang kelokasi untuk mendaftarkan diri mengikuti acara yang akan dihadiri. Kemudian proses berikutnya data tersebut diproses untuk dimasukkan kedalam list peserta acara. Peserta harus melakukan pengecekan beberapa kali untuk pendaftaran tersebut, yang pertama memastikan terdaftar sebagai peserta dalam acara tersebut, kemudian pada saat hari $\mathrm{H}$ acara tersebut berlangsung, peserta harus melakukan pendaftaran ulang untuk memastikan terdaftar dan sudah mendapatkan posisi dalam acara tersebut. Posisi tersebut untuk penempatan tempat dalam acara.

Yang menjadi kendala juga adalah untuk acara yang berlangsung dari tahapan pendaftaran sampai hari $\mathrm{H}$ acara, tidak berlangsung 1 hari, jadi jarak dari pendaftaran dengan hari $\mathrm{H}$ acara berbeda hari dan tanggal. Permasalahan yang terjadi untuk peserta yang bertempat tinggal jauh dari tempat acara yang harus datang beberapa kali untuk proses pendaftaran tersebut. Dan tentunya dengan permasalahan ini akan menjadi kendala karena waktu yang dibutuhkan dan proses yang dilakukan akan membuat kesulitan bagi peserta acara.

\section{Permasalahan}

Berdasarkan hal tersebut maka rumusan masalah dalam penelitian ini adalah :

a. Bagaimana membuat suatu sistem yang dapat membantu permasalahan yang terjadi?

b. Apakah dengan sistem yang baru akan membantu mengurangi permasalahan tersebut?

\section{B. METODE}

Dalam mendapatkan data yang diperlukan maka penelitian menggunakan beberapa metode antara lain metode yang digunakan adalah sebagai berikut :

\section{Metode Pengumpulan Data}

Metode pengumpulan data digunakan untuk memperoleh informasi yang dibutuhkan dalam mendapatkan tujuan penelitian. Metode pengumpulan data dapat dilakukan dengan cara studi pustaka, wawancara dan lain sebagainya.

\section{Metode Analisa}

Dalam metode analisa sistem ini dilakukan melalui beberapa tahap yaitu :

a. Identifikasi persyaratan system

b. Hasil analisa kemudian dibuat laporan sebagai arsip perancangan pada sistem input dan output 
Volume 11 Number 2 November 2021 Page. 85-94

Journal Homepage : http://teknois.stikombinaniaga.ac.id/index.php/JBS

DOI Link : http://doi.org/10.36350/jbs.v11i2

\section{Metode Perancangan Sistem}

Metode perancangan sistem menggunakan metode System Development Life Cycle dengan tahapan model waterfall sebagai berikut:

a. Perencanaan (planning)

Tahap perencanaan adalah tahap awal pengembangan sistem yang mendefinisikan perkiraan kebutuhan-kebutuhan sumber daya, piranti lunak. Tahap ini juga dilakukan dengan beberapa langkah berupa : mendefinisikan masalah, menentukan tujuan sistem, menindentifikasikan masalah, menentukan tujuan sistem, mengidentifikasikan masalah yang muncul dalam proses pengembangan aplikasi dan membuat studi kelayakan

b. Analisis (Analysis)

Tahap ini bertujuan untuk merancangkan sistem baru dengan menggunakan tools atau alat bantu UML sebagai tahap penganalisa struktur.

c. Design

Desain sistem dapat didefinisikan sebagai "tahap setelah analisis dari siklus pengembangan sistem : pendefinisian dari kebutuhan kebutuhan fungsional dan persiapan untuk rancang bangun implementasi; menggambarkan bagaimana suatu sistem dibentuk. "Tujuan dari desain sistem secara umum. Pada tahap desain secara umum komponen komponen sistem informasi dirancang dengan tujuan dikomunikasikan kepada user. Komponen yang di desain secara sistem adalah UI (User Interface), model, output, input, database, teknologi dan control

d. Implementasi (Implementation)

Tahap implementasi adalah dimana rancangan yang dibuat sudah terbentuk dalam suatu kode (program) yang siap untuk digunakan. Langkah langkahnya yaitu : melakukan simulasi, menyiapkan fasilitas fisik dan tools.

\section{HASIL DAN PEMBAHASAN}

\section{Hasil}

Dalam pembahasan dari hasil penelitian ini, ada beberapa penggunaan perancangan sistem untuk membantu menggambarkan tahapan penyelesaian masalah, diantaranya yang pertama penggunaan metode yang digunakan menggambarkan alur perancangan, adalah penggunaan metode SDLC dan tahapan model yang digunakan dalam SDLC tersebut adalah model Air Terjun (waterfall). Dimana penggambaran umumnya adalah dimulai dari analisa desain sistem sampai dengan pemeliharan sistem. Untuk penggambaran perancangan berikutnya digunakan model UML yang menggambarkan gambaran sistem diantaranya Usecase Diagram, activity diagram dan sequence diagram. "Unified Modeling Language (UML) merupakan bahasa standar untuk menuliskan cetak biru (blueprints) dari software". (Pressman, R. S : 2010).

"Use case mendeskripsikan cara pengguna berinteraksi dengan sistem, dengan mendefinisikan langkah-langkah yang dibutuhkan untuk mencapai tujuannya. Variasi dalam urutan langkah-langkah menjelaskan berbagai skenario."(Ferdinand Ariandy Luwinda \& dkk : 2016).

"Sebuah sequence diagram digunakan untuk menunjukkan komunikasi yang dinamis antara objek selama pelaksanaan tugas, berbeda dengan diagram kelas, yang menunjukkan struktur statis dari komponen software". (Pressman, R. S : 2010).

"Sequence diagram menunjukkan pemanggilan metode menggunakan panah horisontal dari caller (pemanggil) ke callee, diberi label dengan nama metode dan parameter (opsional), type, dan return type.”(Ferdinand Ariandy Luwinda \& dkk : 2016).

Umumnya, QR code mampu menyimpan 2089 digit atau 4289 karakter, termasuk tanda baca ataupun karakter spesial di dalamnya. Dengan keunggulan tersebut, maka QR code mampu menampilkan berbagai teks, membuka URL, menyimpan kontak pada buku telepon, dll.

QR code terdiri dari berbagai titik-titik dan suatu spasi yang sudah disusun kedalam bentuk kotak, dan setiap elemen di dalamnya juga memiliki arti masing-masing. Karena adanya elemen tersebut, maka membuat $\mathrm{QR}$ code lebih mudah untuk di scan oleh smartphone dan mampu menampilkan berbagai data ataupun informasi yang dimuat di dalamnya.

$Q R$ Code adalah barcode 2-dimensi yang diperkenalkan pertama kali oleh perusahaan Jepang Denso-Wave pada tahun 1994. Barcode ini pertama kali digunakan untuk pendataan inventaris 
produksi suku cadang kendaraan dan sekarang sudah digunakan dalam berbagai bidang. QR adalah singkatan dari "Quick Response" karena ditujukan untuk diterjemahkan isinya dengan cepat (Rouillard 2008).

$Q R$ Code merupakan salah satu tipe dari barcode yang dapat dibaca menggunakan kamera handphone. Berbeda dengan barcode yang menyimpan informasi secara horizontal, QR Code mampu meyimpan informasi secara horizontal dan vertikal. Oleh karena itu $Q R$ Code dapat menampung informasi yang lebih banyak daripada barcode (David 2007).



Gambar 1 Bentuk QR Code

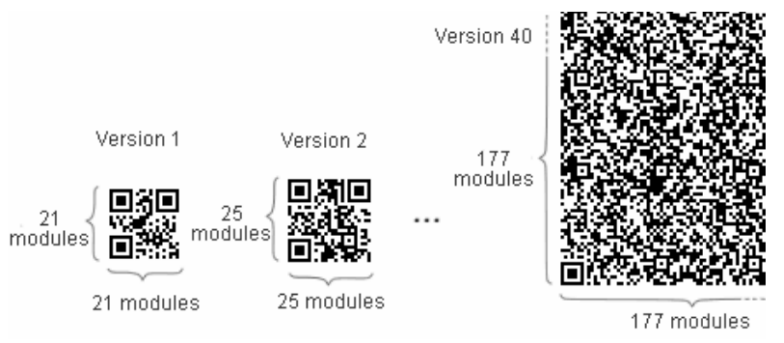

Gambar 2 Versi QR Code

“QR Code dapat menghasilkan 40 versi yang berbeda dari versi 1 (21 x 21 modul) sampai versi 40 (177 x 177 modul). Tingkat versi QR Code 1 dan 2 berbeda 4 modul berlaku sampai dengan versi 40. Setiap versi memiliki konfigurasi atau jumlah modul yang berbeda."(Ariadi:2010).

QR Code memiliki kemampuan mengoreksi kesalahan untuk mengembalikan data jika kode kotor atau rusak. Empat tingkat kesalahan koreksi yang tersedia bagi pengguna, tingkatan ini mampu mengoreksi kesalahan pada QR-Code. Koreksi Kesalahan Pada QR Code.
a. Level L Dapat mengoreksi kesalahan sampai $7 \%$
b. Level M Dapat mengoreksi kesalahan sampai $15 \%$
c. Level Q Dapat mengoreksi kesalahan sampai $25 \%$
d. Level H Dapat mengoreksi kesalahan sampai $30 \%$

\section{Pembahasan}

\section{a. Mengoreksi kesalahan QR Code}

QR Code mampu mengoreksi kesalahan dan pengembalian data dalam pembacaan kode apabila qr code kotor atau rusak. Menurut Denso (Betha dan Husni: 2014), Ada 4 tingkatan koreksi kesalahan dalam QR code :

Tabel 1. Level Koreksi

\begin{tabular}{cc}
\hline \hline $\begin{array}{c}\text { Level Koreksi } \\
\text { Kesalahan }\end{array}$ & $\begin{array}{c}\text { Jumlah Perkiraan } \\
\text { Koreksi }\end{array}$ \\
\hline L & $7 \%$ \\
M & $15 \%$ \\
Q & $25 \%$ \\
H & $30 \%$ \\
\hline \hline
\end{tabular}

Semakin tinggi tingkat koreksi kesalahan semakin besar juga versi qr code. Faktor lokasi dan lingkungan operasi perlu di timbangkan dalam menentukan level QR Code. Level $\mathrm{Q}$ dan $\mathrm{H}$ baik digunakan di pabrik yang kotor, sedangkan L untuk tempat yang bersih. Level yang sering digunakan adalah level $M$ dengan perkiraan koreksi mencapai $15 \%$. 


\section{b. Manfaat $Q R$ code}

Beberapa manfaat yang terdapat pada QR Code antara lain(Betha dan Husni) :

1) Kapasitas tinggi dalam menyimpan data Sebuah $Q R$ Code tunggal dapat menyimpan sampai 7.089 angka.

2) Ukuran yang kecil, Sebuah QR Code dapat menyimpan jumlah data yang sama dengan barcode 1D dan tidak memerlukan ruang besar.

3) Dapat mengoreksi kesalahan, Tergantung pada tingkat koreksi kesalahan yang dipilih, data pada QR code yang kotor atau rusak sampai 30\% dapat diterjemahkan dengan baik.

4) Banyak jenis data, QR Code dapat menangani angka, abjad, simbol, karakter bahasa Jepang, Cina atau Korea dan data biner.

5) Kompensasi distorsi, QR Code tetap dapat dibaca pada permukaan melengkung atau terdistorsi.

6) Kemampuan menghubungkan, Sebuah QR Code dapat dibagi hingga 16 simbol yang lebih kecil agar sesuai dengan ruang. Simbol-simbol kecil yang dibaca sebagai kode tunggal apabila di scan menurut urutan.

Berikut ini adalah kelebihan dari QR Code (Rachmat Suryadithia:2013)

1) Dapat menampung banyak data, seperti alpha numeric 4296 karakter, huruf Kanji, Kana, Hiragana sebanyak 1817 karakter. Symbol biner 2953 karakter dan kontrol codesebanyak lebih dari 7.089 karakter.

2) Dapat dicetak dalam ukuran kecil, lebih kecil dibandingkan barcode pada umumnya.

3) QR Codemampu menyimpan $20 \%$ Lebih data simbol huruf Kanji dibandingkan code2D lainnya.

4) QR Code memiliki kemampuan koreksi kesalahan. Data dapat dipulihkan bahkan jikasebagian simbol QR Codekotor atau rusak. Maksimal30\% dapat dipulihkan.

5) Dapat dibaca dari berbagai macam sudut $360^{\circ}$, melalui pola deteksi dari tiga sudut yang berbeda untuk menjamin kecepatan tinggi dalam membaca simbol QR Code.

6) Informasi yang tersimpan dalam beberapa simbol $Q R$ Code dapat direkonstruksi sebagai simbol data tunggal QR Code. Satu simbol data dapat menampung sampai dengan 16 simbol QR Code, yang memungkinkan pencetakan di tempat yang terbatas.

\section{c. Usecase Diagram}

Penggambaran tentang proses yang terjadi dalam transaksi pendaftaran melalui tahapan tahapan. Dalam penjelasan yang digambarkan dalam bentuk usecase diagram, dijelaskan proses admin ketika menggunakan aplikasi untuk pendaftaran, dimulai dari memasukkan login dan password yang sudah terdaftar dalam database. Admin mempunyai hak akses untuk mengelola datapeserta, membuat penjadwalan pendaftaran suatu acara, dan membuat kode QR untuk peserta sebagai persyaratan apakah peserta sudah terdaftar atau belum. Didalam usecase ini juga terdapat proses transaksi peserta ketika sudah mendapatkan kode QR dan mengaktivasi kode tersebut untuk mengecek apakah peserta tersebut sudah terdaftar atau belum.

Keterangan :

1) Admin melakukan proses login untuk masuk kedalam sistem aplikasi pendaftaran, dimana login dan password tersebut sudah terdaftar dalam database.

2) Terbuka menu utama dan membuka menu master yang terdiri dari : menu daftar acara, daftar peserta dan menu peserta.

3) Admin melakukan pengisian data peserta baru, dengan menekan tombol tambah baru kemudian mengisi data tersebut dan data tersimpan tersebut dalam database.

4) Tahapan berikutnya mengisi data jadwal kegiatan, hal selanjutnya sama seperti proses input data peserta dan data tersebut disimpan ke dalam database, berikutnya admin melakukan pengisian data daftar peserta dari kegiatan tersebut yang kemudian akan dibuatkan kode QR, berikutnya peserta melakukan login \& Password untuk masuk ke aplikasi. 
5) Peserta yang sudah terdaftar dan mendapatkan kode QR, melakukan scan code untuk memastikan atau aktivasi keiutsertaan kegiatan.

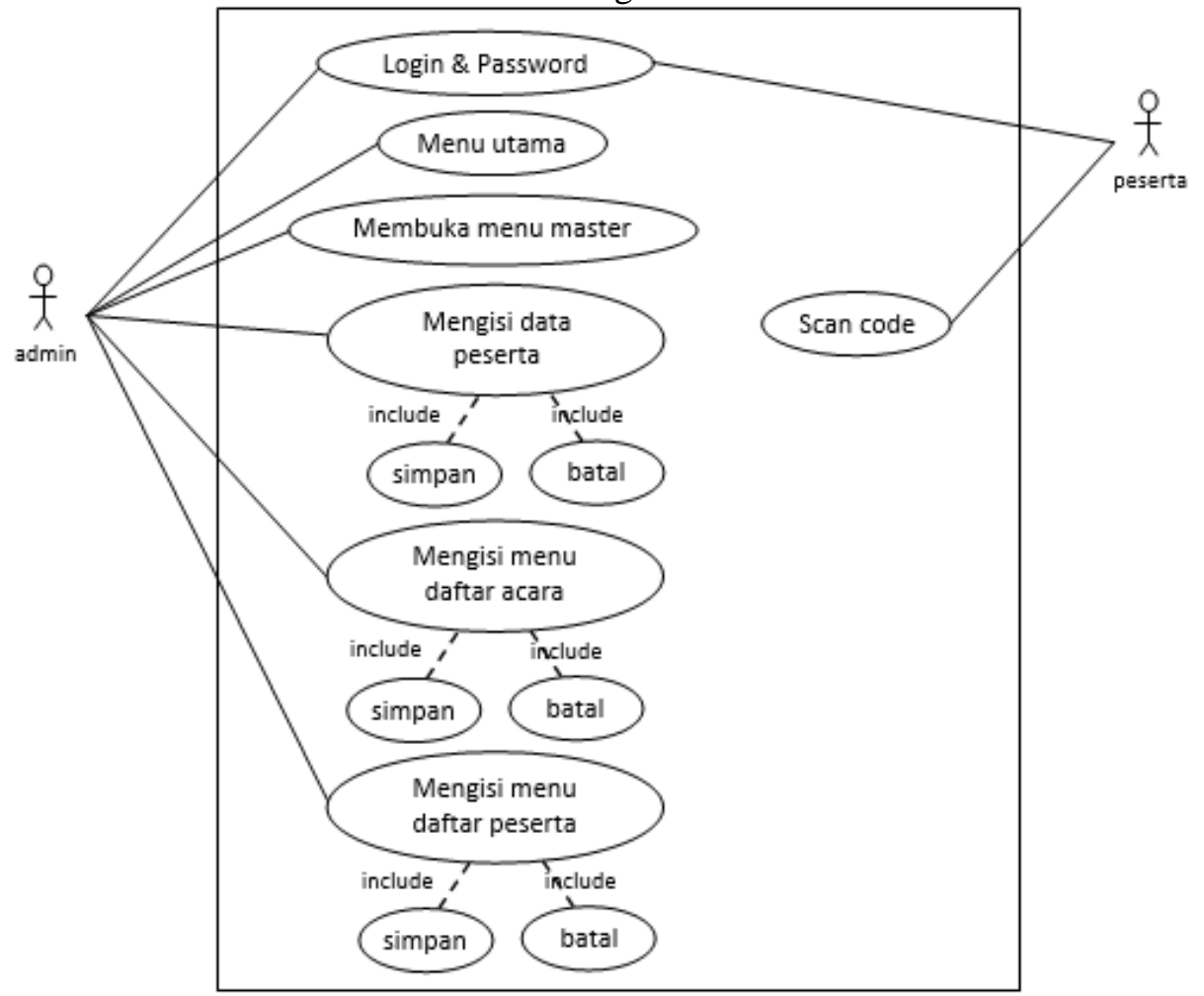

Gambar 3. Usecase Diagram

\section{d. Aktivity Diagram}

\section{1) Aktivity daigram transaksi pendaftaran}

Proses atau tahapan dari transaksi pendaftaran yang digambarkan dalam bentuk aktivity diagram, menjelaskan proses admin melakukan input data kegiatan dan menyimpannya didalam database. Dimulai dari memasukkan login \& password, mengisi data kegiatan dari data peserta, jadwal kegiatan acara sampai dengan pengisian data peserta acara. Setelah proses tersebut dilakukan kemudian data yang sudah di input atau dimasukkan ke dalam sistem disimpan dalam database. Data yang sudah disimpan dalam database kemudian ditampilkan dalam tabel, yang memudahkan admin atau pengguna aplikasi melihat data tersebut.

2) Aktivity diagram transaksi scan code peserta

Proses aktivity diagram ini menjelaskan proses untuk peserta menscan kode yang Sudah didapatkan setelah proses pendataan sebelumnya dilakukan. Peserta menscan kode QR yang sudah didapat dan melihat apakah data tersebut sudah terdafar dan mengecek apakah data yang diinput sudah sesuai atau belum dengan data sipengguna atau peserta acara.

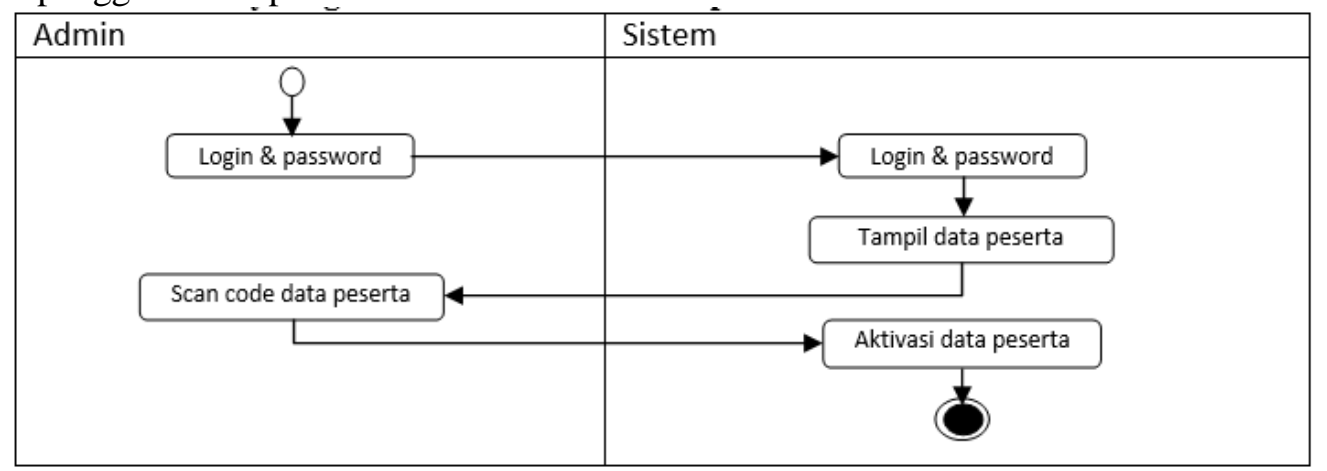

Gambar 4. aktivity diagram transaksi scan code peserta 
Volume 11 Number 2 November 2021 Page. 85-94

Journal Homepage : http://teknois.stikombinaniaga.ac.id/index.php/JBS

DOI Link : http://doi.org/10.36350/jbs.v11i2



Gambar 5. aktivity diagram transaksi pendaftaran

\section{e. Sequence Diagram}

\section{1) Sequence Diagram scan code peserta}

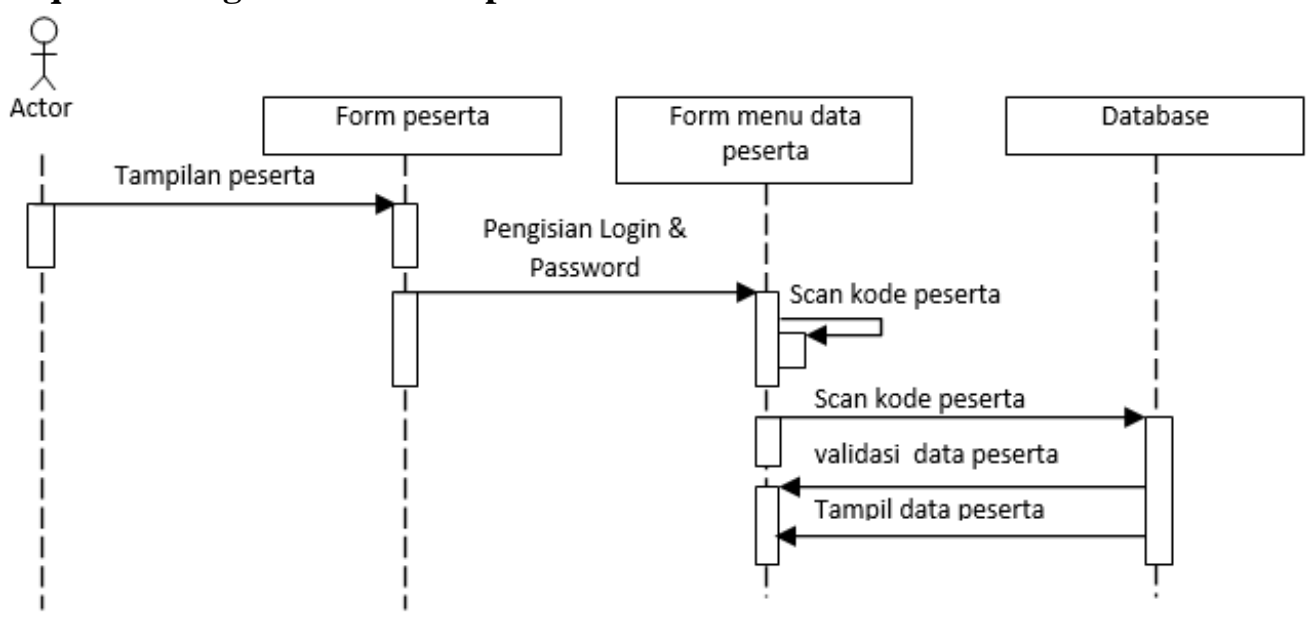

Gambar 6. Sequence Diagram scan code peserta 
Volume 11 Number 2 November 2021 Page. 85-94

Journal Homepage : http://teknois.stikombinaniaga.ac.id/index.php/JBS

DOI Link : http://doi.org/10.36350/jbs.v11i2

2) Sequence Diagram transaksi pendaftaran

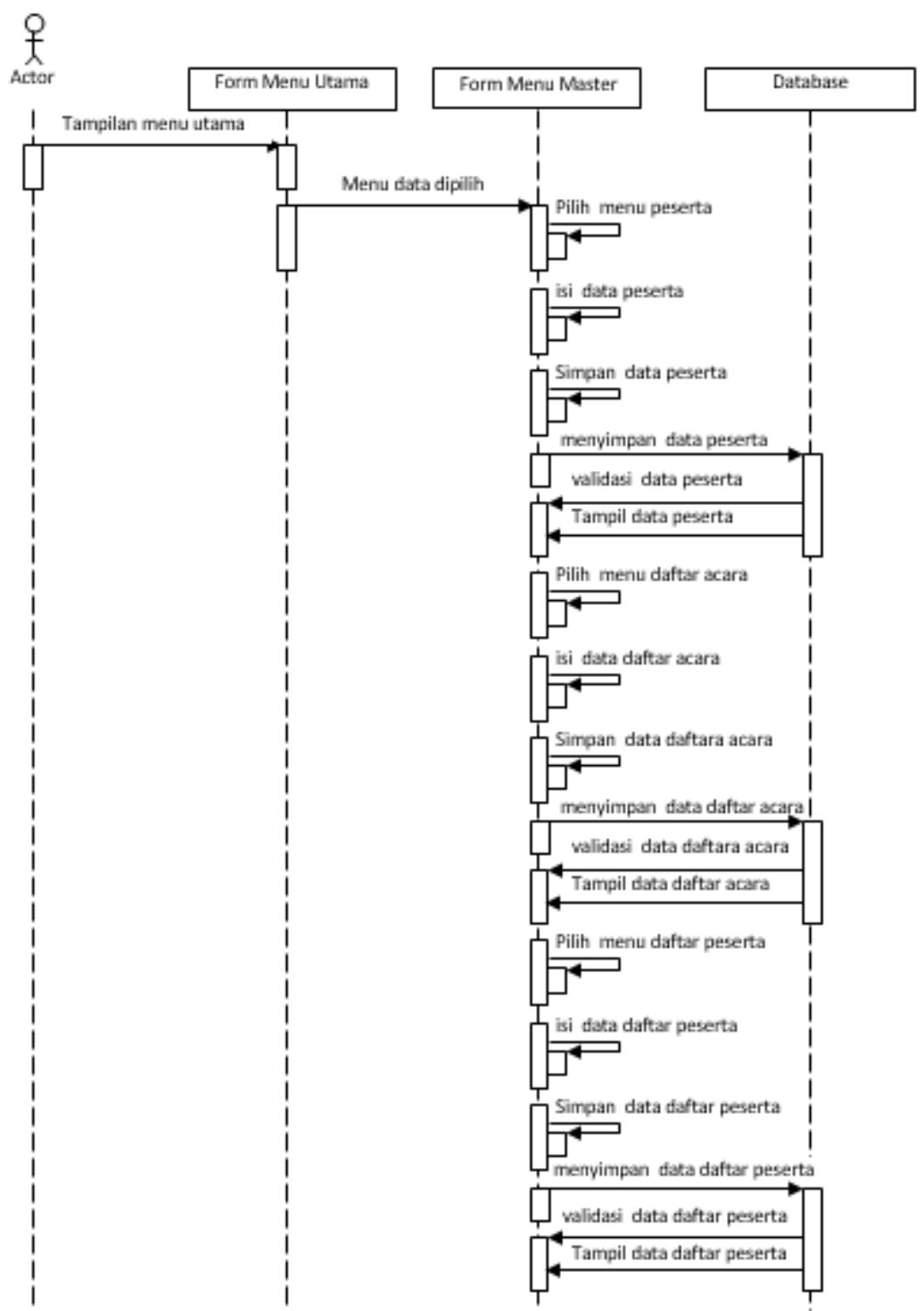

Gambar 7. Sequence Diagram transaksi pendaftaran

f. Perancangan Form aplikasi penerapan QR kode

1) Perancangan Form Peserta (Pengguna aplikasi)

\begin{tabular}{|c|c|c|c|c|}
\hline \multirow{3}{*}{$\begin{array}{l}\text { Administrator Admin } \\
\text { Halaman Utama }\end{array}$} & \multicolumn{4}{|c|}{ Penerapan Quick Response (QR) Code } \\
\hline & \multicolumn{4}{|l|}{ Peserta } \\
\hline & \multicolumn{4}{|c|}{++ Tambah Baru } \\
\hline Daftar Menu & \multicolumn{2}{|l|}{ Show $0 \boldsymbol{\nabla}$ entries } & \multicolumn{2}{|c|}{ Cari } \\
\hline Daftar Jadwal & No Gambar Nama & username & Type & Aksi \\
\hline Daftar Peserta & & & & \\
\hline Peserta & & & & \\
\hline
\end{tabular}

Gambar 8. Form Peserta 
Volume 11 Number 2 November 2021 Page. 85-94 Journal Homepage : http://teknois.stikombinaniaga.ac.id/index.php/JBS

DOI Link : http://doi.org/10.36350/jbs.v11i2

Keterangan : Perancangan form untuk memasukan data peserta kegiatan, dengan menambahkan data baru peserta tersebut.

2) Perancangan Form Daftar Jadwal

\begin{tabular}{|c|c|c|c|c|}
\hline \multirow{3}{*}{$\begin{array}{l}\text { Administrator Admin } \\
\text { Halaman Utama }\end{array}$} & \multicolumn{4}{|c|}{ Penerapan Quick Response (QR) Code } \\
\hline & \multicolumn{4}{|l|}{ Jadwal } \\
\hline & \multicolumn{4}{|c|}{ + Tambah Bart } \\
\hline Daftar Menu & \multicolumn{2}{|l|}{ Show $0 \nabla$ entries } & \multicolumn{2}{|c|}{ Cari $\square$} \\
\hline Daftar Jadwal & No Judul & Detail & Status & Aksi \\
\hline Daftar Peserta & & & & a \\
\hline Peserta & & & & \\
\hline
\end{tabular}

Gambar 9. Form Daftar Jadwal

Keterangan : perancangan form untuk memasukkan data daftar jadwal, memasukkan data baru dengan menekan tombol tambah baru, dan kemudian data diisi dan disimpan dalam database. Hasil dari inputan data akan ditampilkan dalam tabel daftar jadwal.

\section{3) Perancangan Form Scan Code Peserta}



Gambar 10. Form Scan Code Peserta

Keterangan : perancangan form daftar peserta, admin melakukan pengisian data daftar untuk peserta yang sebelumnya data telah dimasukkan di menu peserta, admin memilih tombol tambah baru dan data peserta diambil dari database, hasil dari inputan data daftar peserta ditampilkan dalam tabel form daftar peserta.

\section{KESIMPULAN}

Berdasarkan hasil penelitian yang telah diselesaikan, dapat ditarik kesimpulan sebagai berikut :

1. Dengan membuat suatu perancangan aplikasi yang dapat mempermudah permasalahan yang terjadi. Melakukan analisa permasalahan sampai dengan mendesain perancangan sistem dengan penggunaan alur data yang mempermudah pengerjaan perancangan sistem baru tersebut. Perancangan aplikasi menggunakan bahasa PHP.

2. Pengerjaan sistem pendaftaran yang masih bersifat manual, menimbulkan beberapa pemasalahan, salah satunya efesiensi waktu yang dibutuhkan. Dengan perancangan sistem baru, penggunaan suatu aplikasi yang dapat membantu permasalahan yang ada. Teraturnya penggunaan waktu karena pendaftaran dapat dilakukan memalui Online, sehingga efisiensi waktu dan permasalahn yang lain dapat terpecahkan. 
Volume 11 Number 2 November 2021 Page. 85-94

Journal Homepage : $\underline{\text { http://teknois.stikombinaniaga.ac.id/index.php/JBS }}$

DOI Link : http://doi.org/10.36350/jbs.v11i2

\section{E. DAFTAR PUSTAKA}

[1] Ariadi. Penerapan Aplikasi QR Code Reader dan QR Code Generator Secara Mobile Untuk mengelola Benda Cagar Budaya Kota Salatiga, Jurnal sistem Informasi 2010 p-ISSN: 1979-0767.

[2] Betha dan Husni. 2014. Pemrograman WEB dengan HTML. Bandung:Informatika Bandung

[3] Ferdinand Ariandy Luwinda \& DKK, APLIKASI PENYEDIA INFORMASI PRODUK DAN PENANDA STAN PADA PAMERAN MENGGUNAKAN QR CODE BERBASIS ANDROID Jurnal Teknik dan Ilmu Komputer, Vol. 05 No. 17, Jan - Mar 2016.

[4] Pressman, R. S. 2010. Software Engineering: A Practitioner's Approach (7th ed.). New York: McGraw-Hill.

[5] Rachmat Suryadithia, Faktor-Faktor yang Mempengaruhi Penggunaan QR Code pada Era Digitalisasi dengan Metode Usability, PARADIGMA VOL. XV. NO 2 SEPTEMBER 2013.

[6] Rouillard, J. (2008). Contextual QR Codes, Proceedings of the Third International Multi-Conference on Computing in the Global Information Technology. 